\title{
Tutkija liikkeessä
}

Sarjassa tutustutaan aikuiskasvatuksen ajankohtaisiin tutkijoihin, tutkimuksiin ja tapahtumiin. Sarjaa tuottaa Aikuiskasvatuksen Tutkimusseura ATS.

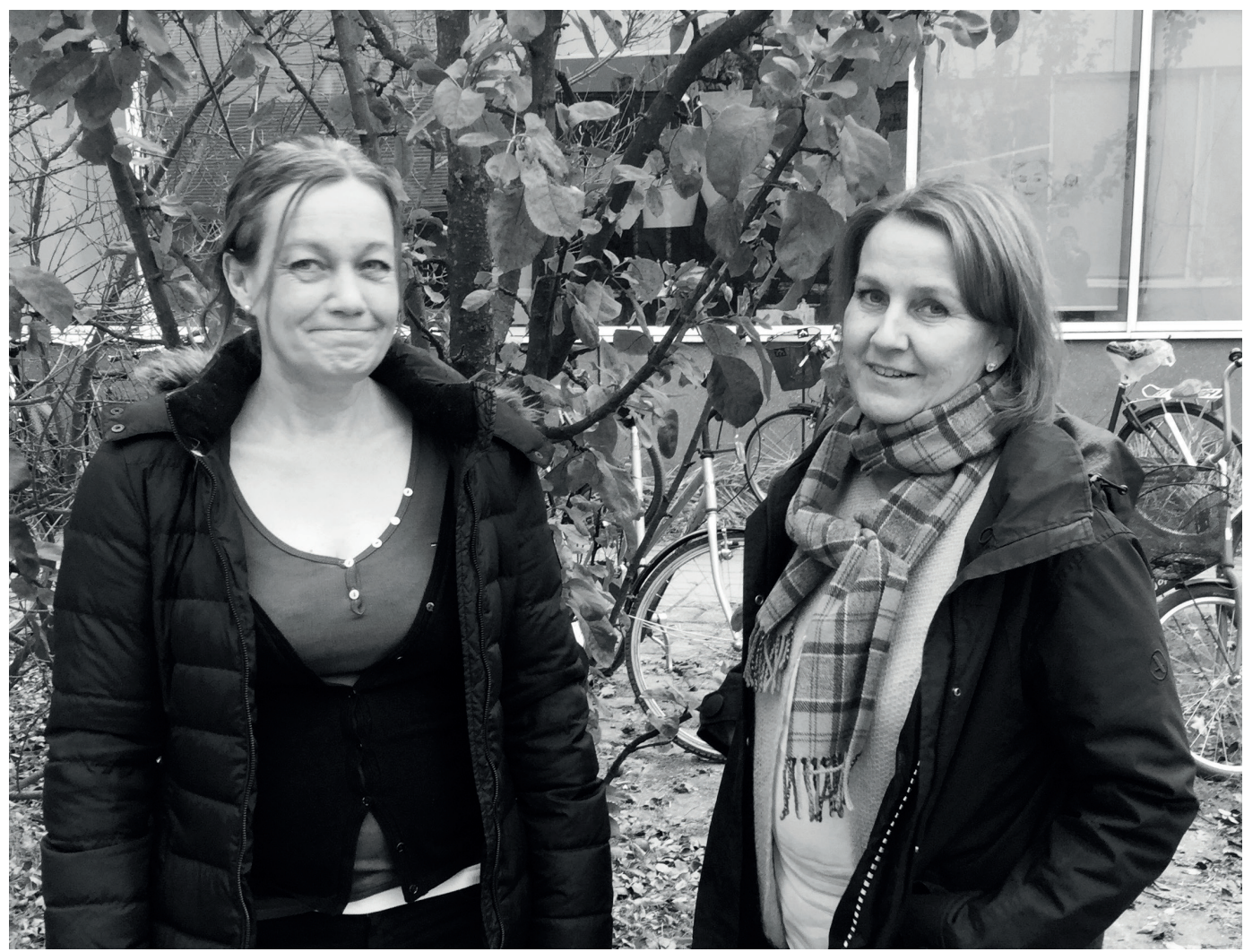

\section{Kristiina Ojala}

- KM, tohtorikoulutettava, Kasvatustieteiden laitos, CELE, Turun yliopisto.

- Työskennellyt viisi vuotta kasvatustieteiden laitoksella sekä toiminut tutkijana myös RUSEssa ja työväenopistossa.

\section{Anne Laiho}

- $K T$, yliopistonlehtori, koulutussosiologian dosentti, Kasvatustieteiden laitos, CELE, Turun yliopisto

- Työskennellyt 17 vuotta kasvatustieteiden laitoksella sekä toiminut opettajana ammatillisessa koulutuksessa 


\section{Miten päädyitte aikuiskasvatuksen alalle?}

Anne: Siirryin 17 vuotta sitten kasvatustieteiden laitokselle tuntiopettajaksi ammattikorkeakoulusta. Laitos oli tuolloin pienempi, ja "ammattimainen" tutkijakoulutus rakentui muutaman assistentuurin varaan. Opetuskokemusta jo omaavana ajauduin laitoksella opetustehtäviin ja tohtoroiduin opetusvakanssien ohessa vuonna 2005. Tarkastelin väitöstutkimuksessani sairaanhoitajien yliopistollisen koulutuksen kehittymistä ja hoitotieteen vakiintumista Pohjoismaissa. Miellän itseni opettaja-tutkijaksi, joka tasapainoilee opetuksen ja tutkimuksen ristipaineissa. Opetuksen ja tutkimuksen "pyhä liitto" näyttäytyy työssäni välillä vapaana seurustelusuhteena, välillä vakaana aviollisena liittona, mutta ajautuu ajoittain avioeron partaalle (Laiho \& Jauhiainen 2012).

Kristiina: Hakeuduin jatko-opiskelijaksi syksyllä 2011. Olin onnekas ja sain tutkijakoulupaikan heti seuraavan vuoden alussa. Innostus väitöskirjan kirjoittamiseen oli virinnyt jo aiempien tutkimustyövuosieni aikana ja päätös siitä syntyi vanhempainvapaalla. Kirjoitan väitöskirjaa päätyönäni, ja väittelen YAMK-tutkinnoista (ylempi AMK-tutkinto) näillä näkymin 2017. Tutkimustyön rinnalla olen pitänyt opetustehtävistä, jotka liittyvät pääasiassa proseminaaritutkielmien ohjaamiseen ja kasvatustieteen tutorointiin. Ne ovat tuoneet tutkimustyöhöni antoisaa vaihtelua. Tohtorikoulutus on muuttunut ja tehostunut valtavasti, mikä näkyy tiukkana rahoituksesta kilpailemisena, työn nopeatempoistumisena ja tutkijakoulutuksen kansainvälistymisenä. Myös odotukset yliopisto-opetukseen pätevöitymisestä ovat kasvaneet.

\section{Mitä tutkitte tällä hetkellä?}

Anne: Tutkimukseni on vakiintunut kolmen teeman ympärille. Olen ensinnäkin kiinnostunut akateemisesta työstä ja erityisesti opetustyöstä. Toiseksi oma ammatillinen taustani sairaanhoitajana ja väitöskirjani tematiikka ovat pitäneet minut kiinni aiheissa, jotka käsittelevät terveysalan ammatteja, niiden kou- lutusta ja tietoperustaa. Tuorein julkaisuni (Laiho \& Riikonen 2016) aihepiiristä löytyy Aikuiskasvatuksen teemanumerosta (3/2016), jossa yhdeksän tutkijan voimin ja kolmen eri artikkelin näkökulmasta pureudutaan tyttö-, nais- ja hoivakansalaisuuteen. Kolmanneksi sukupuolen ja koulutuksen väliset yhteydet ovat aina puhutelleet minua, ja sukupuolinäkökulma on ollut keskeinen juonne opetuksessani ja tutkimuksessani (Vuolanto \& Laiho 2016). Myös aikuiskoulutuksen "luokkahuoneissa" on tarvetta sukupuolinäkökulmaiselle tutkimukselle.

Kristiina: Loppusuoralla oleva väitöskirjani käsittelee vuonna 2005 vakinaistettujen YAMK-tutkintojen merkitystä, hyötyä ja kilpailukykyä suomalaisilla työmarkkinoilla ja korkeakoulujärjestelmässä. Olen kiinnostunut erityisesti siitä, minkälainen tutkinnon kilpailuasetelma työmarkkinoilla on suhteessa yliopistolliseen maisterin tutkintoon. Tähän teemaan liittyy myös tuorein julkaisuni (Ojala \& Isopahkala-Bouret 2015). Väitöstutkimukseni aihe juontaa juurensa Turun yliopiston Koulutussosiologian tutkimuskeskuksesta (RUSE), jossa tutkin YAMK-tutkintoja viitisen vuotta. Jo silloin kiinnostuin tutkintojen kehityksen seuraamisesta. YAMK-tutkintoja on myös tärkeä tutkia, koska tutkintojen määrä kasvaa jatkuvasti, ja niiden painoarvo ja merkitys alkavat yhä enemmän näkyä työ- ja koulutusmarkkinoilla. Myös aiempi tutkimustyöni Varsinais-Suomen kansalais- ja työväenopistojen vaikuttavuudesta Turun suomenkielisessä työväenopistossa on linkittynyt aikuiskasvatukseen ja -koulutukseen (esim. Klemelä \& Ojala 2002).

\section{Mitkä alan teoriat inspiroivat tutkimustanne?}

Anne: Minua ovat viime aikoina kiinnostaneet hallinnan tutkimuksen teoriat ja käytäntöteoriat. Esimerkiksi Keijo Räsäsen ja Marja-Liisa Truxin (2012) teos Työkirja. Ammattilaisen paluu on ollut varsin inspiroiva ja käyttökelpoinen, niin tutkimuksen, opetuksen kuin oman työn pohtimisen näkökulmasta.

Kristiina: Olen väitöskirjassani nojannut perinteiseen inhimillisen pääoman teoriaa. Yksilön inhimillisellä pääomalla on yhä suurempi merkitys 
työmarkkinaresurssina jatkuvasti muuttuvilla ja kilpailukeskeisillä työmarkkinoilla. YAMK-tutkintojen vakinaistuminen maisteritutkintojen rinnalle sekä yleensäkin korkeakoulutuksen laajentuminen vahvistavat tutkintojen roolia työmarkkinoille pääsyssä sekä siellä kilpailukykyisen toiminnan edellytyksenä.

\section{Mikä liikuttaa tällä hetkellä?}

Yhdessä: Konkreettisesti nyt marraskuussa 2016 meitä liikuttaa Kasvatustieteen päivät Turun yliopistossa. Päivien teema "Eriarvoistuva maailma - tasa-arvoistava koulu?" haastaa tarkastelemaan maailmassa samanaikaisesti käynnissä olevia eriarvoistavia sekä tasa-arvoistavia kehityssuuntia. Koulutusta on pidetty Suomessa yhtenä tärkeimmistä tasa-arvon lähteistä. Päivillä pohditaan esimerkiksi sitä, mikä on koulutuksen mahdollisuus eriarvoistumiskehityksen katkaisemiseen. Myös aikuiskasvatuksen ja -koulutuksen rooli eriarvoistuvassa ja kulttuurisesti moninaisessa yhteiskunnassa aktualisoituu uusilla tavoilla.

Meitä huolestuttavat ammatilliseen koulutukseen kohdentuvat leikkaukset. Siitä huolimatta, että työelämän murros haastaa uudistamaan ammatillista koulutusta vastaamaan tulevaisuuden tarpeita, tuntuvat leikkaukset kohtuuttoman suurilta. Onneksi täältä Turun seudulta löytyy ilonaiheitakin. Telakkateollisuuden hyvät uutiset vaikuttavat alueen työllisyyteen ja alihankkijoiden kautta työllisyysheijastukset leviävät laajemmallekin Suomeen. Samalla se tarkoittaa, että ammattitaitoa ja osaamista tarvitaan telakkateollisuuden kaikilla tasoilla, mikä haastaa aikuis- ja ammatillista koulutusta monilla aloilla tuottaen myös uusia tutkimustarpeita.

\section{Miltä alan tulevaisuus näyttää?}

Yhdessä: Aikuiskasvatuksella on yhä tärkeämpi tehtävä, koska uudelleen kouluttautumisesta on tullut yleisempää sekä itsensä kehittämisestä ja osaamisen ylläpitämisestä työmarkkinoilla lähes selviytymisen elinehto. Nämä nostavat alan merkitystä elinikäisen oppimisen puolestapuhujana ja osaajien kehittäjänä. Laitoksellamme on tehty myös merkittävää avoimeen yliopistoon liittyvää tutkimusta, mikä avaa näkökulmia avoimen yliopiston opiskelijoille tarjottavaan opetukseen ja sen kehittämiseen. Toki toivoisimme myös entistä vahvempaa otetta aikuiskasvatuksen ja -koulutuksen tutkimiseen.

Odotamme aikuiskasvatustieteeltä kriittisiä avauksia, sillä vaikka oppiminen ja koulutus mielletään lähtökohtaisesti positiiviseksi ja hyödylliseksi, liittyy koulutukseen aina myös intressien kamppailua ja tarkoittamattomia seurauksia. Koulutus voi näyttäytyä pakkona, kontrollin muotona tai ihmisarvon mittana. Koulutusinstituutioita kouraisevat myös uudet hallinnan tavat, jotka ylenkatsovat niiden historiaa, kulttuurista luonnetta ja pyrkivät standardisoimaan lähtökohdiltaan hyvin erilaisia koulutuksen toimintaympäristöjä. Tietoa, tutkimusta ja koulutusta arvioidaan taloudellisten arvojen näkökulmasta, vaikka tiede-, opetus- ja opiskeluyhteisöillä on muitakin ulottuvuuksia. Yhtä lailla niin vapaan sivistystyön kuin esimerkiksi yliopistojen on taivuttava markkinalogiikkaan. Emmekö samalla menetä jotakin olennaista aikuiskasvatuksen ja -koulutuksen erityislaadusta?

\section{JULKAISUJA:}

Klemelä, K. \& Ojala, K. (2002). "Tää on tiedollinen ja taidollinen turvaverkko". Varsinaissuomalaisten kansalaisopistojen asema, vaikuttavuus ja merkitys kuntapäättäjien, opistojen rehtoreiden ja opiskelijoiden näkökulmasta. Turun suomenkielinen työväenopisto.

Laiho, A. \& Riikonen, T. (2016). Sairaanhoitajakoulutus ja naiskansalaisuus: hyvinvointivaltion huomasta kilpailuyhteiskunnan realiteetteihin. Aikuiskasvatus 36(3), 179-194.

Laiho, A. \& Jauhiainen, A. (2012). Kohti post-humboldtilaista yliopistoa - opetus-tutkimusyhteys uusliberalistisessa yliopistossa. Teoksessa J. Kivirauma, A. Jauhiainen, P. Seppälä \& T. Kaunisto (toim.) Koulutuksen yhteiskunnallinen ymmärrys. Kasvatusalan tutkimuksia 59, 62-88.

Ojala, K. \& Isopahkala-Bouret, U. (2015). Ylemmän ammattikorkeakoulututkinnon ja maisterin tutkinnon suorittaneet työmarkkinoilla - tutkintojen statuserot, työkokemus ja työtehtävien eriytyminen kilpailuasetelman määrittäjinä. Teoksessa H. Aittola \& J. Ursin (toim.) Eriarvoistuva korkeakoulutus? Koulutuksen tutkimuslaitos. Jyväskylän yliopisto.

Vuolanto, P. \& Laiho. A. (2016). Gender perspectives in nursing research: a theoretical tresure chest or a 'thorn in the side'. Minerva (tulossa). 